\title{
Effects of creep feeder design and feed accessibility on preweaning pig performance and the proportion of pigs consuming creep feed
}

Rommel C. Sulabo, MS, PhD; Michael D. Tokach, MS, PhD; Joel M. DeRouchey, MS, PhD; Steve S. Dritz, DVM, PhD; Robert D. Goodband, MS, PhD; Jim L. Nelssen, MS, PhD

\section{Summary}

Objective: To determine the effects of creep feeder design and feed accessibility on preweaning performance and the proportion of eaters of creep feed.

Materials and methods: A total of 54 sows and their litters were assigned to three treatments: rotary feeder with hopper, rotary feeder without hopper, and pan feeder. A creep diet with $1.0 \%$ chromic oxide was offered ad libitum from Day 18 until weaning (Day 21). Fecal samples were collected from piglets with sterile swabs 3 to 12 hours before weaning. Piglets were categorized as "eaters" when either of the two fecal samples was colored green; otherwise, they were categorized as "non-eaters." Pigs were weighed Days 0 (birth), 18, and 21 , and litter creep-feed disappearance was determined daily.

Results: There were no differences $(P>.05)$ in preweaning gains and weaning weights of pigs and litters using the different types of creep feeder. Litters provided creep feed using the rotary feeder with the hopper had 2.7 times lower total creep-feed disappearance than litters using the rotary feeder without the hopper and the pan feeder $(P<.001)$. However, the rotary feeder with the hopper produced the highest proportion of pigs consuming creep feed within the litter $(80 \% ; P<.001)$.

Implications: The proper choice of creep feeder is essential to manage creep feeding and to maximize the number of eaters in the litter. A creep feeder with a hopper may create more eaters with less feed wastage.

Keywords: swine, creep feed, growth, feeder design, suckling pig

Received: November 3, 2009

Accepted: December 11, 2009
Resumen - Efectos del diseño del comedero de lechones en lactancia y el acceso al alimento en el desempeño de estos cerdos y la proporción que consumen alimento

Objetivo: Determinar los efectos del diseño del comedero de lechones en lactancia y el acceso al alimento en el desempeño de estos cerdos y la proporción de animales que consumieron alimento.

Materiales y métodos: Un total de 54 hembras y sus camadas fueron asignadas a tres tratamientos: comedero giratorio con depósito, comedero giratorio sin depósito, y comedero de charola. Se ofreció una dieta de lactancia ad libitum con $1.0 \%$ de óxido crómico del Día 18 hasta el destete (Día

RCS, MDT, JMDR, RDG, JLN: Department of Animal Sciences and Industry, Kansas State University, Manhattan, Kansas.

SSD: Food Animal Health and Management Center, Kansas State University, Manhattan, Kansas.

Contribution no. 09-298-J from the Kansas Agricultural Experiment Station.

Corresponding author: Dr Bob Goodband, 242 Weber Hall, Kansas State University, Manhattan, KS 66506-0201; Tel: 785-532-1228; Fax: 785-532-7059; E-mail: Goodbandaksu.edu.

This article is available online at http://www.aasv.org/shap.html.

Sulabo RC, Tokach MD, DeRouchey JM, et al. Effects of creep feeder design and feed accessibility on preweaning pig performance and the proportion of pigs consuming creep feed. J Swine Health Prod. 2010;18(4):174-181.
21). Se recolectaron muestras fecales de lechones con hisopos estériles 3 y 12 horas antes del destete. Los lechones se clasificaron como "comensales" cuando cualquiera de las dos muestras fueron de color verde: 0 (nacimiento), 18, y 21, y la desaparición del alimento de la camada se determinó diariamente.

Resultados: No hubo diferencias $(P>.05)$ en la ganancia de peso durante la lactancia y en el peso al destete de los cerdos y de las camadas con ninguno de los comederos utilizados. Las camadas provistas con alimento de camada en el comedero giratorio con depósito tuvieron 2.7 veces menos desaparición de alimento que las camadas utilizando el comedero giratorio sin deposito y el comedero de charola $(P<.001)$. El comedero giratorio con deposito produjo la mayor proporción de cerdos que consumieron alimento dentro de la camada $(80 \% ; P<.001)$.

Implicaciones: La selección adecuada del comedero es esencial para manejar la alimentación de camada y para maximizar el número de comensales en la camada. Un comedero de camada con depósito puede crear más comensales con menos desperdicio de alimento.

Résumé - Effets du design des mangeoires et de l'accessibilité à la nourriture sur les performances des porcs en période pré-sevrage et la proportion des porcs consommant de la moulée

Objectif: Déterminer les effets du design des mangeoires et de l'accessibilité à la nourriture sur les performances pré-sevrage et la proportion des consommateurs de moulée.

Matériels et méthodes: Un total de 54 truies et leurs portées ont été assignées à trois 
traitements: mangeoire rotative avec une trémie, mangeoire rotative sans trémie, et un bac. Une diète de type moulée contenant $1.0 \%$ d'oxyde chromique était offerte ad libitum à compter du Jour 18 jusqu'au sevrage (Jour 21). Des échantillons de feces ont été prélevés des porcelets à l'aide d'écouvillons stériles 3 à 12 heures avant le sevrage. Les porcelets ont été catégorisés comme "consommateurs" lorsqu'un des deux échantillons de feces avait une coloration verte; sinon, ils étaient catégorisés comme "non-consommateurs." Les porcs ont été pesés aux Jours 0 (naissance), 18, et 21, et la disparition de moulée déterminée quotidiennement.

Résultats: Il n'y avait aucune différence $(P>.05)$ dans les gains pré-sevrage et les poids au sevrage des porcs et portées utilisant les différents types de mangeoires. Les portées recevant de la moulée à l'aide d'une mangeoire rotative avec la trémie présentaient une disparition de moulée 2.7 fois inférieure que les portées utilisant la mangeoire rotative sans la trémie et le bac $(P<.001)$. Toutefois, la mangeoire rotative avec la trémie entraînait la plus forte proportion de porcs consommant de la moulée à l'intérieur de la portée $(80 \% ; P<.001)$.

Implications: Le choix approprié de mangeoires est essentiel afin de gérer la prise de moulée et de maximiser le nombre de consommateurs dans la portée. Une mangeoire avec une trémie pourrait créer plus de consommateurs avec moins de gaspillage de nourriture.

A $s$ pig production systems are moving toward later weaning, there is greater interest in nutritional strategies that can increase nutrient availability to suckling piglets and improve weaning weights and postweaning performance. The practice of providing a solid, highly digestible diet to piglets during lactation, or "creep feeding," is one of the strategies that received significant attention.

A number of studies, mostly in late-weaned piglets, have shown positive benefits of creep feeding in initiating and promoting gut and digestive-enzyme development, ${ }^{1-5}$ reducing preweaning mortality, ${ }^{6}$ increasing preweaning growth rate and weaning weights, ${ }^{7-9}$ and improving postweaning performance. ${ }^{10,11}$ However, these effects have been inconsistent, mainly because of low and highly variable creep-feed consumption between and within litters. ${ }^{12-14}$
Inert markers, such as chromic oxide added to the creep feed, can be used to identify individual pigs within a litter that actually consume creep feed, by detection of the marker in the feces. ${ }^{11,13,15}$ Recently, a number of creep-feeding studies evaluating individual piglets have consistently shown that "eaters" (ie, piglets that positively consumed creep feed) have significantly higher postweaning feed intake and better growth performance than non-eaters of creep feed or non-creep-fed pigs. ${ }^{6,11,16-20}$ If creepfeeding behavior can be encouraged and more eaters can be created within a litter, nursery performance can be improved. It is therefore important to determine dietary and nondietary factors that can stimulate individual piglets to consume creep feed prior to weaning. Identifying these factors can also help in understanding and managing the variability in consumption typically observed with creep feeding.

Creep-feeder design may be an important factor. Few studies have evaluated the effect of different creep-feeder designs and creep-feed accessibility on feeding behavior, intake, and performance of suckling piglets. Some of these studies have shown positive improvements on feeder visiting time and intakes of suckling pigs when a familiar trough was used ${ }^{21}$ or when feeding space was increased. ${ }^{22,23}$ However, these studies evaluated whole litters and did not differentiate between eaters and non-eaters of creep feed within a litter. Moreover, to the best of our knowledge, the effect of different types of creep feeders on creating eaters has never been evaluated. The objective of this experiment was to determine the effects of different creep-feeder designs and increasing creep-feed accessibility on the rate of creating eaters and on preweaning performance.

\section{Materials and methods}

All animal procedures used in this study were reviewed and approved by the Kansas State University Institutional Animal Care and Use Committee.

\section{Study animals}

A total of 54 sows (PIC Line 1050) and their litters were used in this study conducted at the Kansas State University Swine Research and Teaching Center farrowing facility in Manhattan, Kansas. Sows in this experiment were from two batches of 27 sows farrowed in June and July, 2007. Cross-fostering was performed within 48 hours post farrowing to standardize litter weights and litter size (> 10 pigs).

\section{Experimental design}

Sows were blocked according to parity and date of farrowing and allotted to three experimental treatments in a randomized complete block design. The sow or litter was the experimental unit, with 18 replicates per treatment group. Three types of creep-feeder designs were tested in this study. Treatment One used a rotary creep feeder (Rotecna Mini Hopper Pan; Rotecna SA, Spain), which is $27 \mathrm{~cm}$ in diameter, $86 \mathrm{~cm}$ in linear feeding space, and $5.3 \mathrm{~cm}$ deep, with five feeding spaces (Figure 1). This feeder design has a 6-L capacity hopper, which is adjustable to five different settings to allow ad libitum feeding and minimize feed wastage. The hopper has a curved rim and wings that help separate piglets while feeding. The feeder can be latched to the flooring of the pen and fixed on a specific location within the farrowing crate. This feeder design was used in our previous creep-feeding studies, and therefore served as the control treatment in this study. In past studies, $60 \%$ to $70 \%$ of piglets were categorized as eaters when this feeder was used. $6,24,25$

Treatment Two used a rotary creep feeder without a hopper (Rotecna Mini Pan; Rotecna SA, Spain; Figure 2). This feeder design has the same dimensions as the feeder in Treatment One, and can also be latched on a specific location within the farrowing crate. This feeder represents conventional bowl feeders that are commonly used in the industry.

Treatment Three used a stainless pan feeder that is $102 \mathrm{~cm}$ long, $13.5 \mathrm{~cm}$ wide, and 2.5 $\mathrm{cm}$ deep (Figure 3). The feeder was placed under the divider of two farrowing crates, which provides a feeding trough for two adjacent crates and a 2.8 -cm width per trough.

The rotary creep feeder (Treatments One and Two) was placed on the opposite side of the farrowing crate from the heat lamp. This ensured creep feed accessibility, prevented soiling of the creep feed, and allowed piglets unhindered suckling of the sow.

A pelleted creep diet (2-mm pellets; 3494 kcal metabolizable energy [ME] per kg, $1.56 \%$ standardized ileal digestible lysine) with $1.0 \%$ chromic oxide was offered ad libitum from Day 18 until weaning on Day 21 (Table 1), for a creep-feeding duration of 3 days. The 3-day duration of creep feeding used in this study was chosen for a number of reasons. Sulabo et $\mathrm{al}^{6}$ showed that $75 \%$ of total creep-feed intake was 
Figure 1: Rotary creep feeder with hopper (Rotecna Mini Hopper Pan; Rotecna SA, Spain). The feeder is $27 \mathrm{~cm}$ in diameter, $86 \mathrm{~cm}$ in linear feeding space, and $5.3 \mathrm{~cm}$ deep with five feeding spaces. The 6-L capacity hopper is adjustable to five settings to allow ad libitum feeding and minimize feed wastage.

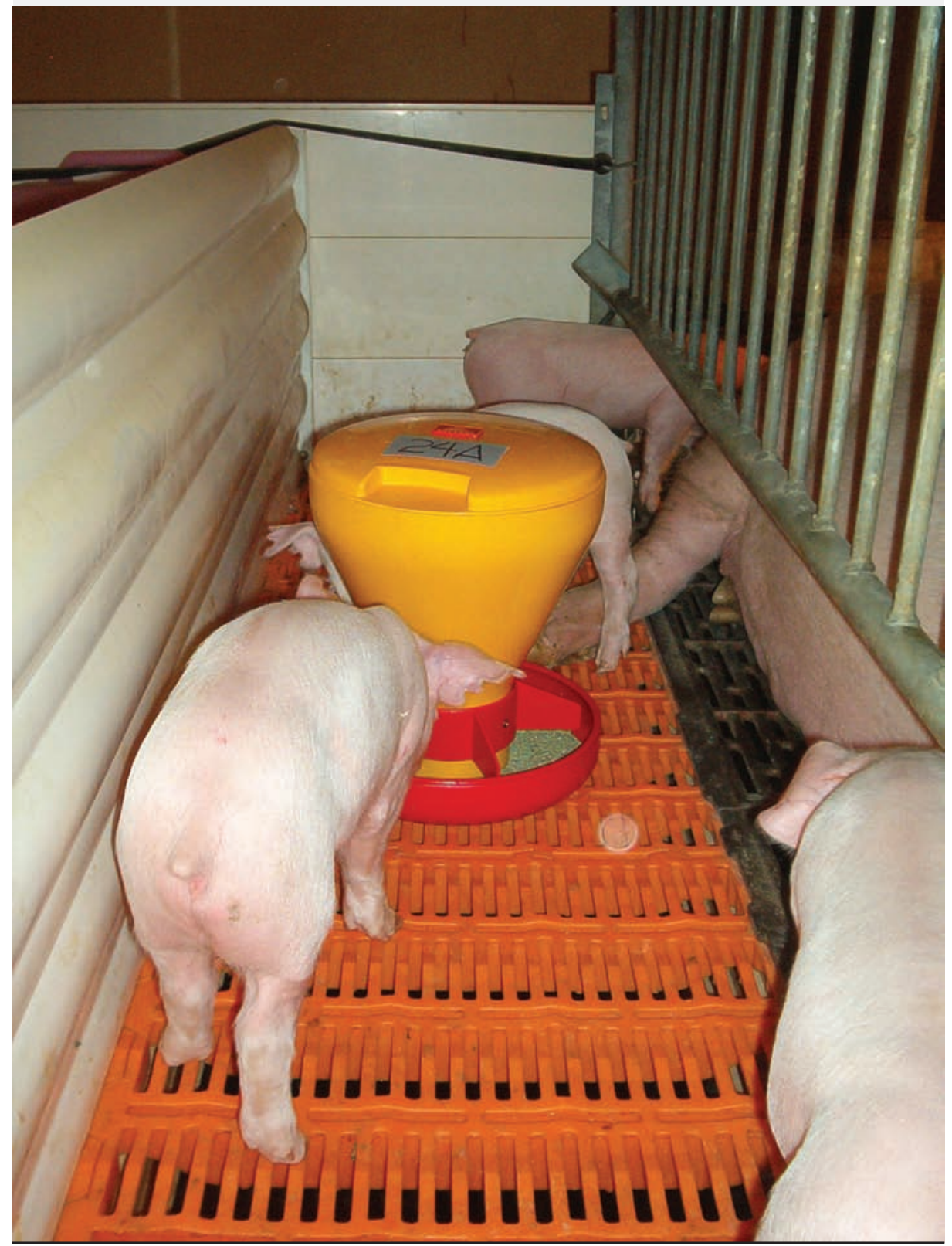

consumed in the last 3 days prior to weaning (Day 21), when creep feed was provided for a period of 18 days. In another study, initiating creep feeding at a later age did not detrimentally affect creep-feed intake. ${ }^{20}$ Older piglets readily accepted creep feed and consumed at least as much feed as piglets started on creep feed at an earlier age. In fact, this study showed that creep feeding for only 2 days was enough to create $70 \%$ eaters, compared to $80 \%$ for litters creep fed for 13 days. Therefore, creep feeding for 3 days allows enough difference to investigate the effect of creepfeeder design on the proportion of eaters without detriment to total creep-feed consumption.

For Treatment One, sufficient amounts of creep feed were placed in the hopper to ensure that feed was always available. The adjustment of the hopper was checked daily to allow ad libitum feeding and control feed wastage. For Treatments Two and Three, small amounts of creep feed were placed in the feeder whenever it was empty. Feeders were checked at 2-hour intervals for 12 hours each day. The daily frequency of adding creep feed was recorded for every crate. A single lactation diet $(3503 \mathrm{kcal} \mathrm{ME}$ per $\mathrm{kg}, 0.97 \%$ standardized ileal digestible lysine) was used in the experiment (Table 1). Sows were allowed free access to feed throughout lactation. Water was available at all times for both sows and their litters through nipple and bowl drinkers, respectively.

\section{Performance and fecal sample collection}

Piglets were weighed individually at Days 0 (birth), 18, and 21 (weaning). Amount of creep feed offered was weighed daily. Creep feed that was not consumed at this time was collected and weighed. All piglets were evaluated for consumption category (noneater versus eater of creep feed) between 3 and 12 hours before weaning by evaluating fecal material for green color provided by the chromic oxide marker in the creep diet. ${ }^{12,14}$ On the morning of Day 20, a fecal swab was obtained from each piglet and a piglet was categorized as an eater if green color was visible in the fecal sample. Piglets without evidence of creep-feed consumption were re-sampled after 9 to 12 hours. Piglets were categorized as non-eaters when no green color was detected in all collected samples.

Sows were weighed post farrowing and at weaning. Weekly feed intake of the sows was recorded to calculate total and average daily feed intake. General health of the sows and piglets was checked daily. Temperature in the farrowing facility was maintained at a minimum of $20^{\circ} \mathrm{C}$, and supplementary heat was provided to the piglets using heat lamps. Periodic and cumulative average daily gain and creep feed intake (as feed disappearance) were calculated for each treatment group.

\section{Statistical analysis}

Data were analyzed as a randomized complete block design using PROC MIXED of SAS (SAS Institute Inc, Cary, North Carolina). Sow or litter was the experimental unit. The model included treatment and block as the fixed and random effects, respectively. When treatment effect was a significant source of variation, differences were determined using the PDIFF option of SAS. Least squares means were calculated for each independent variable. The effect of different creep-feeder designs on the proportion of eaters of creep feed was analyzed using the chi-square test in SAS. Statistical significance was set at $P<.05$ for all statistical tests. 
Figure 2: Rotary creep feeder without a hopper (Rotecna Mini Pan; Rotecna SA, Spain), representing conventional bowl feeders commonly used in the industry. The feeder is $27 \mathrm{~cm}$ in diameter, $86 \mathrm{~cm}$ in linear feeding space, and $5.3 \mathrm{~cm}$ deep.

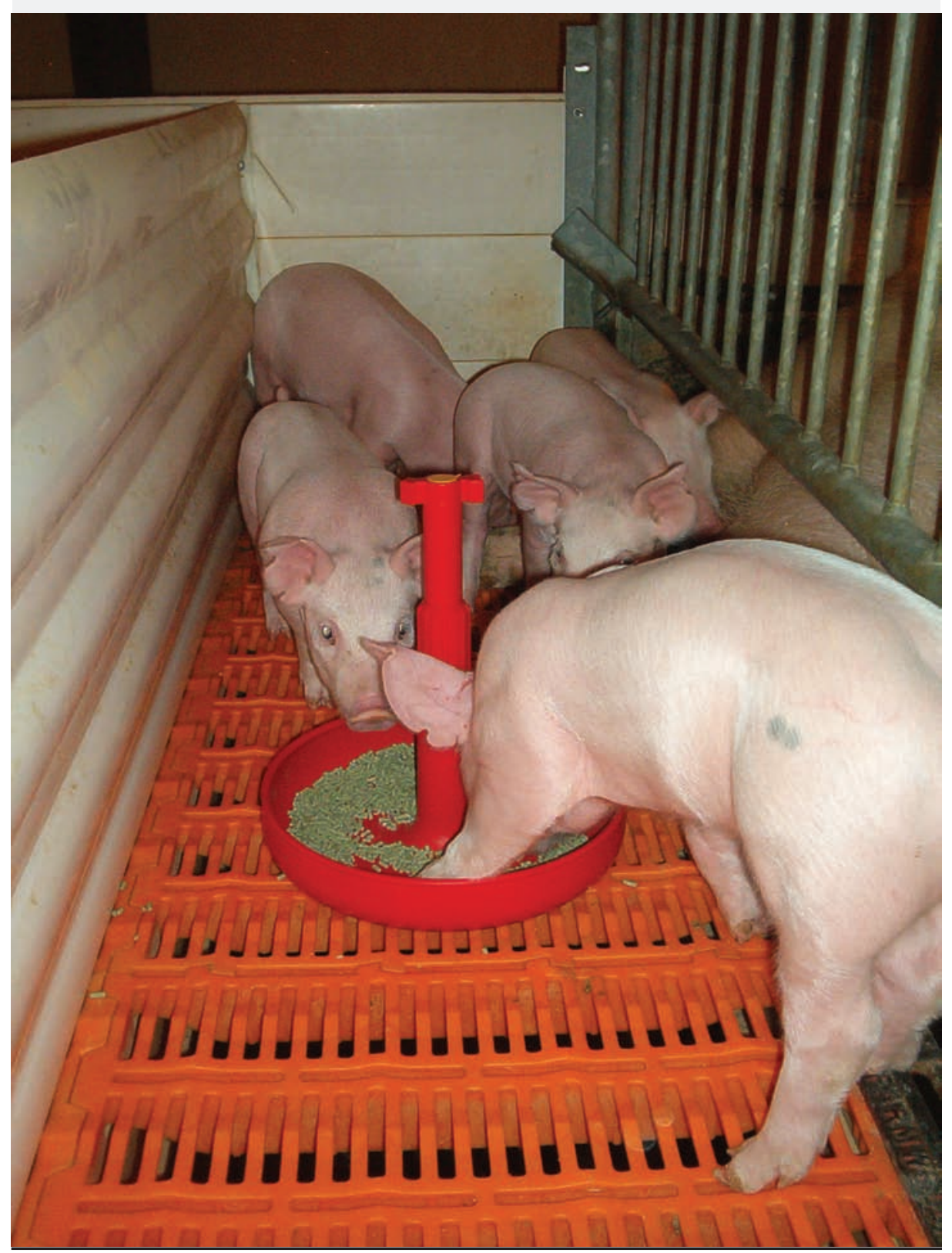

\section{Results}

The technical-performance parameters of sows used in this study are shown in Table 2. Experimental sows had an average parity of $2.1 \pm 0.2$ and lactation length of $21.1 \pm$ 0.3 days. There were no differences $(P>.05)$ in postfarrowing weight, weaning weight, or lactation weight loss among the treatments. Total and average daily feed intake of sows throughout lactation also did not differ $(P>.05)$ among treatments.

The effect of creep-feeder design on pig and litter performance is shown in Table 3. There were no differences $(P>.05)$ in pig and litter weights at weaning among litters using the different types of creep feeder. Total and daily gains of pigs and litters also did not differ $(P>.05)$ across treatments. However, litters using the rotary feeder with the hopper had 2.7 times lower total creep feed disappearance than litters using the rotary feeder without the hopper and the pan feeder $(P<.001)$. Feeders were filled for an average of 1.0 time per 12 hours for the rotary feeder with hopper, 2.3 times per 12 hours for the rotary feeder without hopper, and 4.2 times per 12 hours for the pan feeder.

Type of creep feeder influenced the proportion of eaters created among piglets pro- vided with creep feed $(P<.001)$. In litters using the rotary feeder with the hopper, $69 \%$ of suckling piglets were categorized as eaters at weaning. This rate was consistent with that in our previous creep-feeding studies that used the same feeder and creep diet. $^{20,21}$ On the other hand, litters using the rotary feeder without the hopper had $22 \%$ fewer eaters than litters using the rotary feeder with the hopper $(P<.001)$, and litters using the pan feeder had 27\% fewer eaters than litters using the rotary feeder with the hopper $(P<.001)$.

\section{Discussion}

The lack of differences in pig and litter growth rates among treatments suggests that a large proportion of creep feed offered to litters using the rotary feeder without the hopper and the pan feeder was not consumed but rather wasted. The design of these two feeders is more open, and creep feed is more accessible to piglets than it is in the feeder with the hopper. However, it was observed that these two feeders also allowed some piglets to root or lie in the feeder and push feed out of it, which eventually reduced the availability and accessibility of creep feed to other piglets. The higher creep-feed disappearance with the pan feeder also confirmed results of other studies in which increased access to creep feed was provided. ${ }^{18,19}$ The pan feeder in this study was designed to provide more feeding spaces than the rotary feeder, but it was observed that piglets more often approached and consumed creep feed with their bodies parallel to the feeder rather than eating side by side.

Addition of the hopper to the rotary feeder was associated with lower total creep-feed disappearance but not with different growth performance. This feeder design has been used in our previous creep-feeding trials and is capable of measuring no creep-feed intake to very small amounts of intake for whole litters. ${ }^{6,24,25}$ This indicates the feeder's ability to control feed wastage. Therefore, it can be assumed that total creep feed disappearance measured with this feeder in this study is close to the true intake of creep feed by the litter. Certain aspects of this feeder design may help explain the lower creep-feed disappearance. The conical shape, curved rim, and wings at the bottom of the hopper prevented piglets from rooting in or standing over the troughs, or pushing creep feed out of them. 
Figure 3: Stainless steel pan feeder $102 \mathrm{~cm}$ long, $13.5 \mathrm{~cm}$ wide and $2.5 \mathrm{~cm}$ deep. The feeder is placed under the divider between two farrowing crates, providing two feeding troughs per feeder with a $2.8-\mathrm{cm}$ width per trough.

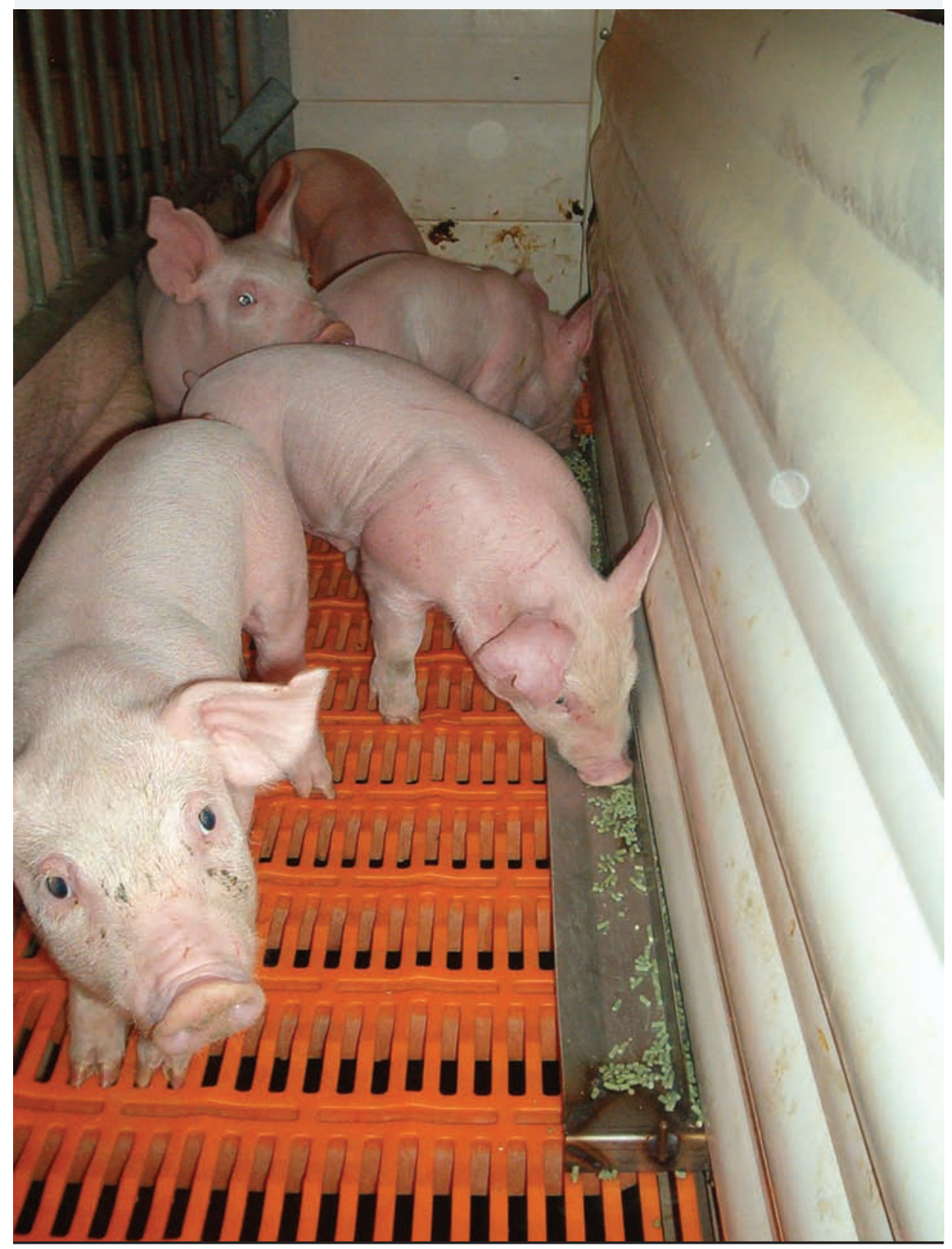

The hopper was also adjusted daily to manage the amount of feed that flowed out of the gap, which controlled the level of feed in the trough.

Though the rotary feeder with hopper allowed ad libitum feeding, the daily weighing and re-introduction of the feeder to the litter was counted as one feeding per day. The higher feeding frequency for both the rotary feeder without the hopper and the pan feeder was intended to minimize feed wastage. In creep feeding, the typical recommendation is to feed small amounts frequently to stimulate intake and manage feed wastage. ${ }^{26}$ This method was performed for both the rotary feeder without hopper and the pan feeder. However, it still allowed higher creep-feed disappearance than did the feeder with the hopper. This also demonstrated the extra effort needed to manage these creep feeders, which in the end, provided no positive returns.

The higher rate of eaters created in litters using the rotary feeder with the hopper may be a function of both feeder design and piglet creep-feed consumption. Addition of the hopper to the rotary feeder was associated with a significantly higher percentage of eaters, which may be partially attributed to providing continuous availability of feed in the troughs, with less feed wastage. In a recent study evaluating chromic oxide as a marker for identifying creep-feedeating piglets, eaters were identified as piglets consuming creep feed containing chromic oxide in appreciable amounts or on multiple days. ${ }^{15}$ Therefore, this feeder enabled more piglets in the litter to consume significant amounts of creep feed. This further supports the assumption that creep-feed disappearance measured with this feeder is close to the true value of litter creep-feed intake.

The lower rate of eaters generated from litters using either the rotary feeder without the hopper or the pan feeder also supports the notion that more creep feed was wasted than consumed. Greater accessibility and increased feeding spaces resulted in higher creep-feed disappearance, but did not produce more eaters. This is contrary to the assumption of previous studies, in which increased feeding space and accessibility were thought to encourage more piglets to imitate others at the feeder and stimulate initial intake of creep feed. ${ }^{9,17-19}$ The smaller number of eaters in this study suggests that less creep feed was available in these feeders for piglets to consume in appreciable amounts. Moreover, the rate of feed wastage due to physical activity of piglets in the feeder may be greater than their rate of consumption. Since creep diets are usually expensive, minimizing feed wastage will be an important consideration for management of creep feeding.

\section{Implications}

- Under the conditions of this study, the rotary feeder with the hopper creates the most eaters with the lowest creepfeed disappearance.

- Increasing feeding space and feed accessibility leads to higher creep-feed disappearance, but does not generate more eaters.

- The proper choice of creep feeder is essential to manage creep feeding and to maximize the number of eaters in the litter.

\section{References}

1. Aumaitre A. Development of enzyme activity in the digestive tract of the suckling pig: nutrition significance and implications for weaning. World Rev Anim Prod. 1972;8:54-68.

2. de Passille AMB, Pelletier G, Menard J, Morisset J. Relationships of weight gain and behavior to digestive organ weight and enzyme activities in piglets. J Anim Sci. 1989;67:2921-2929. 
Table 1: Composition of the creep and lactation diets (as-fed basis) in a study conducted at a research farrowing facility

\begin{tabular}{|c|c|c|}
\hline Parameter & Creep* & Lactation $\dagger$ \\
\hline \multicolumn{3}{|l|}{ Ingredient (\%) } \\
\hline Corn & 6.30 & 60.00 \\
\hline Soybean meal ( $46.5 \%$ crude protein) & 2.32 & 31.20 \\
\hline Spray-dried whey & 25.00 & 0.00 \\
\hline Fine ground oat groats & 30.00 & 0.00 \\
\hline Extruded soy protein concentrate & 10.00 & 0.00 \\
\hline Spray-dried animal plasma & 6.00 & 0.00 \\
\hline Select menhaden fish meal & 6.00 & 0.00 \\
\hline Lactose & 5.00 & 0.00 \\
\hline Choice white grease & 5.00 & 5.00 \\
\hline Monocalcium phosphate (21\% phosphorus) & 0.35 & 1.45 \\
\hline Chromic oxide & 1.00 & 0.00 \\
\hline Antibiotic $\ddagger$ & 1.00 & 0.00 \\
\hline Limestone & 0.40 & 1.20 \\
\hline Zinc oxide & 0.38 & 0.00 \\
\hline Salt (NaCl) & 0.30 & 0.50 \\
\hline L-lysine $\mathrm{HCl}$ & 0.15 & 0.00 \\
\hline DL-methionine & 0.15 & 0.00 \\
\hline Trace mineral premix§ & 0.15 & 0.15 \\
\hline Vitamin premixף & 0.25 & 0.25 \\
\hline Sow add pack ${ }^{* *}$ & 0.00 & 0.25 \\
\hline Acidifiert† & 0.20 & 0.00 \\
\hline Vitamin E (20,000 IU) & 0.05 & 0.00 \\
\hline Total & 100.00 & 100.00 \\
\hline \multicolumn{3}{|l|}{ Calculated analysis } \\
\hline Crude protein (\%) & 23.9 & 19.6 \\
\hline SID Lysine (\%) & 1.56 & 0.97 \\
\hline ME (kcal/kg) & 3495 & 3503 \\
\hline Calcium (\%) & 0.79 & 0.87 \\
\hline Available phosphorus (\%) & 0.56 & 0.38 \\
\hline SID lysine ME (g/Mcal) & 4.47 & 2.77 \\
\hline
\end{tabular}

* Diet fed in pellet form (2-mm pellets).

$\dagger$ Diet fed in meal form throughout lactation.

$\ddagger$ Contained $140 \mathrm{mg}$ of neomycin sulfate and $140 \mathrm{mg}$ of oxytetracycline $\mathrm{HCl}$ per $\mathrm{kg}$ of complete diet.

$\S$ Provided per kg of complete diet: Cu, 16.5 mg; Fe, 165.4 mg; Mn, 39.7 mg; Se, 0.30 mg; Zn, $165.4 \mathrm{mg} ; \mathrm{l}, 0.30 \mathrm{mg}$.

ๆ Provided per kg of complete diet: vitamin A, 11,023 IU; vitamin D, 1378 IU; vitamin E, 44 IU; vitamin K, $4 \mathrm{mg}$ (as menadione dimethylpyrimidinol bisulfate); niacin, $50 \mathrm{mg}$; pantothenic acid, $28 \mathrm{mg}$ (as D-calcium pantothenate); riboflavin, $8 \mathrm{mg}$; vitamin $\mathrm{B}_{12}, 0.04 \mathrm{mg}$; phytase, 750 FYT (Ronozyme P; DSM Nutritionals Products, Parsipanny, New Jersey).

** Sow add pack provided the following nutrients per kg of complete diet:vitamin E, $22 \mathrm{IU}$; biotin, $0.22 \mathrm{mg}$; folic acid, $1.65 \mathrm{mg}$; pyridoxine, $5 \mathrm{mg}$ (as pyridoxine $\mathrm{HCl}$ ); choline, $551 \mathrm{mg}$ (as choline $\mathrm{Cl}$ ); L-carnitine, $50 \mathrm{mg}$; chromium, $0.20 \mathrm{mg}$ (as chromium picolinate).

$\dagger \dagger$ Calcium propionate.

$\mathrm{SID}=$ standardized ileal digestible; $\mathrm{ME}=$ metabolizable energy
3. Nabuurs MJ, Hoogendoorn A, van Zijderveldvan Bemmel A. Effect of supplementary feeding during the sucking period on net absorption from the small intestine of weaned pigs. Res Vet Sci. 1996;61:72-77.

4. Pluske JR, Hampson DJ, Williams IH. Factors influencing the structure and function of the small intestine in the weaned pig: a review. Livest Prod Sci. 1997;51:215-236.

5. Kuller WI, van Beers-Schreurs HMG, Soede NM, Langendijk P, Taverne MAM, Kemp B, Verheijden JHM. Intermittent suckling: Effect of feed intake before weaning on net absorption in the small intestine. Livest Sci. 2007;108:99-101.

*6. Sulabo RC, Tokach MD, Jacela JY, Nelssen JL, Dritz SS, DeRouchey JM, Goodband RD. Effects of lactation feed intake and creep feeding on sow and piglet performance [abstract]. J Anim Sci. 2008;85(suppl 2):197.

7. Lawlor PG, Lynch PB, Caffrey PJ, O'Doherty $J V$. Effect of pre- and post-weaning management on subsequent pig performance to slaughter and carcass quality. Anim Sci. 2002;75:245-256.

8. Fraser D, Feddes JJR, Pajor EA. The relationship between creep feeding behavior of piglets and adaptation to weaning: Effect of diet quality. Can J Anim Sci. 1994;74:1-6.

9. Wattanakul W, Bulman CA, Edge HL, Edwards SA. The effect of creep feed presentation method on feeding behaviour, intake and performance of suckling piglets. Appl Anim Behav Sci. 2005;92:27-36.

*10. English PR, Robb CM, Dias MFM. Evaluation of creep feeding using a highly-digestible diet for litters weaned at 4 weeks of age [abstract]. Anim Prod. 1980;30:496.

11. Bruininx EMAM, Binnendijk GP, van der Peet-Schwering CMC, Schrama JW, den Hartog LA, Everts H, Beynen AC. Effect of creep feed consumption on individual feed intake characteristics and performance of group-housed weanling pigs. J Anim Sci. 2002;80:1413-1418.

12. Okai DB, Aherne FX, Hardin ET. Effect of creep and starter composition on feed intake and performance of young pigs. Can J Anim Sci. 1976;56:573-586.

13. Barnett KL, Kornegay ET, Risley CR, Lindemann MD, Schurig GG. Characterization of creep feed consumption and its subsequent effects on immune response, scouring index and performance of weanling pigs. J Anim Sci. 1989;67:2698-2708.

14. Pajor EA, Fraser D, Kramer DL. Consumption of solid food by suckling pigs: Individual variation and relation to weight gain. Appl Anim Behav Sci. 1991;32:139-155.

15. Kuller WI, van Beers-Schreurs MG, Soede NM, Taverne MAM, Kemp B, Verheijden JHM. Addition of chromic oxide to creep feed as a feed marker for selection of creep feed-eating suckling pigs. Am J Vet Res. 2007;68:748-752.

16. Bruininx EMAM, Schellingerhout AB, Binnendijk GP, van der Peet-Schwering CMC, Schrama JW, den Hartog LA, Everts H, Beynen AC. Individually assessed creep feed consumption by suckled piglets: influence on post-weaning food intake characteristics and indicators of gut structure and hind-gut fermentation. Anim Sci. 2004;78:67-75.

17. Pluske JR, Kim JC, Hansen CF, Mullan BP, Payne HG, Hampson DJ, Callesen J, Wilson RH. Piglet growth before and after weaning in relation to a qualitative estimate of solid (creep) feed intake during lactation: a pilot study. Arch Anim Nutr. 2007;61:469-480. 
Table 2: Sow technical parameters in a study to determine the effect of creepfeeder design in a farrowing research facility*

\begin{tabular}{|c|c|c|c|c|c|}
\hline \multirow[b]{2}{*}{ Treatment } & \multicolumn{3}{|c|}{ Creep feeder design } & \multirow[b]{2}{*}{ SED $\dagger$} & \multirow[b]{2}{*}{$P \ddagger$} \\
\hline & $\begin{array}{l}\text { Rotary feeder } \\
\text { with hopper }\end{array}$ & $\begin{array}{c}\text { Rotary feeder } \\
\text { without hopper }\end{array}$ & $\begin{array}{c}\text { Pan } \\
\text { feeder }\end{array}$ & & \\
\hline No. of litters & 18 & 18 & 18 & NA & NA \\
\hline No. of pigs & 189 & 188 & 185 & NA & NA \\
\hline $\begin{array}{l}\text { Average } \\
\text { parity }\end{array}$ & 2.1 & 2.2 & 2.0 & 0.1 & .23 \\
\hline $\begin{array}{l}\text { Lactation } \\
\text { length (days) }\end{array}$ & 21.1 & 21.2 & 21.2 & 0.2 & .60 \\
\hline \multicolumn{6}{|c|}{ Sow weight (kg) } \\
\hline $\begin{array}{l}\text { Post } \\
\text { farrowing }\end{array}$ & 228.6 & 231.8 & 228.1 & 8.7 & .90 \\
\hline Weaning & 216.8 & 220.0 & 219.5 & 7.8 & .90 \\
\hline Change & -11.8 & -11.8 & -8.6 & 2.5 & .56 \\
\hline \multicolumn{6}{|c|}{ Lactation feed intake (kg) } \\
\hline Total & 103.1 & 105.2 & 111.8 & 5.7 & .30 \\
\hline ADFI & 5.1 & 5.2 & 5.5 & 0.3 & .35 \\
\hline \multicolumn{6}{|c|}{$\begin{array}{l}\text { Two groups of sows ( } \mathrm{N}=54 \text {; PIC Line } 1050 \text { ) were blocked according to day of farrow- } \\
\text { ing and parity and allotted to the three treatments. Creep feed with } 1.0 \% \text { chromic } \\
\text { oxide was offered ad libitum from Day } 18 \text { to weaning (Day 21). }\end{array}$} \\
\hline \multicolumn{6}{|c|}{$\dagger$ Standard error of the difference. } \\
\hline \multicolumn{6}{|c|}{$\begin{array}{l}¥ P \text { value for the creep-feeder design treatments. Data were analyzed as a randomized } \\
\text { complete block design using PROC MIXED of SAS, with sow as the experimental } \\
\text { unit. When treatment effect was a significant source of variation, differences were } \\
\text { determined using the PDIFF option of SAS. }\end{array}$} \\
\hline \multicolumn{6}{|c|}{$\mathrm{NA}=$ not applicable; $\mathrm{ADFI}=$ average daily feed intake } \\
\hline
\end{tabular}

18. Callesen J, Halas D, Thorup F, Bach Knudsen KE, Kim JC, Mullan BP, Wilson RH, Pluske $J R$. The influence of nutritional and management factors on piglet weight gain to weaning in a commercial herd in Denmark. Livest Sci. 2007;108:117-119.

19. Callesen J, Halas D, Thorup F, Bach Knudsen KE, Kim JC, Mullan BP, Hampson DJ, Wilson $\mathrm{RH}$, Pluske JR. The effects of weaning age, diet composition, and categorization of creep feed intake by piglets on diarrhea and performance after weaning. Livest Sci. 2007;108:120-123.

20. Kuller WI, Soede NM, van Beers-Schreurs HMG, Langendijk P, Taverne MAM, Kemp B, Verheijden JHM. Effects of intermittent suckling and creep feed intake on pig performance from birth to slaughter. J Anim Sci. 2007;85:1295-1301.

21. Delumeau O, Meunier-Salaün MC. Effect of early trough familiarity on the creep feeding behaviour in suckling piglets and after weaning. Behav Process. 1995;34:185-196.

22. Appleby MC, Pajor EA, Fraser D. Effect of management options on creep feeding by piglets. Anim Prod. 1991;53:361-366.
23. Appleby MC, Pajor EA, Fraser D. Individual variation in feeding and growth of piglets: effect of increased access to creep food. Anim Prod. 1992;55:147-152.

*24. Sulabo RC, Tokach MD, Wiedmann EJ, Jacela JY, Nelssen JL, Dritz SS, DeRouchey JM, Goodband RD. Effects of varying creep feeding duration on pre-weaning performance and the proportion of pigs consuming creep feed [abstract]. J Anim Sci. 2008;85(suppl 2):198.

*25. Sulabo RC, DeRouchey JM, Tokach MD, Risley CR, Goodband RD, Dritz SS, Nelssen JL. Effects of adding an enhanced flavor to the creep feed on the proportion of piglets consuming creep feed and pre-weaning performance [abstract]. J Anim Sci. 2008;86(suppl 2):778.

26. Mavromichalis I. Creep feeding. Applied Nutrition for Young Pigs. Wallingford, UK: CAB International; 2006:245-253.

* Non-refereed references. 
Table 3: Pig and litter performance (least squares means) in a study comparing effects of creep-feeder design in a research farrowing facility*

\section{Treatment}

\begin{tabular}{ccccc}
\multicolumn{4}{c}{ Creep feeder design } & \\
\cline { 1 - 2 } $\begin{array}{c}\text { Rotary } \\
\text { feeder } \\
\text { with } \\
\text { hopper }\end{array}$ & $\begin{array}{c}\text { Rotary } \\
\text { feeder } \\
\text { without } \\
\text { hopper }\end{array}$ & $\begin{array}{c}\text { Pan } \\
\text { feeder }\end{array}$ & SED $\dagger$ & $P \ddagger$ \\
18 & 18 & 18 & NA & NA \\
10.5 & 10.4 & 10.3 & 0.27 & .70 \\
10.5 & 10.4 & 10.3 & 0.27 & .70
\end{tabular}

\section{Pig weight (kg)}

$\begin{array}{lccccc}\text { Post fostering } & 1.36 & 1.37 & 1.37 & 0.02 & .96 \\ \text { Day 18 (start creep) } & 4.90 & 5.14 & 5.17 & 0.12 & .21 \\ \text { Day 21 (weaning) } & 5.63 & 5.94 & 5.96 & 0.14 & .18 \\ \text { Total gain (Days 18-21) } & 0.73 & 0.80 & 0.79 & 0.03 & .20 \\ \text { Daily gain (Days 18-21) } & 0.24 & 0.27 & 0.26 & 0.01 & .20 \\ \text { Litter weight (kg) } & & & & & \\ \text { Post fostering } & 14.32 & 14.23 & 14.04 & 0.38 & .66 \\ \text { Day 18 (start creep) } & 51.43 & 53.33 & 53.21 & 1.85 & .58 \\ \text { Day 21 (weaning) } & 59.10 & 61.66 & 61.31 & 2.13 & .51 \\ \text { Total gain Days 18-21 (kg) } & 7.67 & 8.33 & 8.10 & 0.35 & .31 \\ \text { Daily gain Days 18-21 (kg) } & 2.56 & 2.78 & 2.70 & 0.12 & .31 \\ \text { Creep feed } & & & & & \\ \text { Creep feed disappearance (kg)§ } & 0.44^{\mathrm{a}} & 1.18^{\mathrm{b}} & 1.24^{\mathrm{b}} & 0.07 & .01 \\ \text { Proportion of eaters (\%) } & 69.3^{\mathrm{a}} & 47.3^{\mathrm{b}} & 41.6^{\mathrm{b}} & 4.4 & .01\end{array}$

* Two groups of sows ( $\mathrm{N}=54$; PIC Line 1050) were blocked according to day of farrowing and parity and allotted to the three treatments. Pigs were cross-fostered within 48 hours post farrowing. Creep feed with $1.0 \%$ chromic oxide was offered ad libitum from Day 18 to weaning at Day 21.

$\dagger$ Standard error of the difference.

$\ddagger P$ value for the creep-feeder design treatments. Data were analyzed as a randomized complete block design using PROC MIXED of SAS, with litter as the experimental unit. When treatment effect was a significant source of variation, differences were determined using the PDIFF option of SAS. The effect of creep feeder design on the proportion of eaters of creep feed was analyzed using the chi-square test in SAS.

$\S$ Total per litter.

ab Means within a row with different superscripts differ $(P<.01)$. 